\title{
Comparison of the Effect of (Child-oriented and Teacher-oriented) Educational Methods on the Motor Skills Development of Children
}

\author{
Fatemeh Kardan $^{* 1}$, Farhad Qadiri \\ 1. M.A. in Motor Behavior, Department of Sport Management and Motor Behavior, Faculty of Physical Education, University of \\ Kharazmi, Tehran, Iran \\ 2. Assistant Professor, Department of Sport Management and Motor Behavior, Faculty of Physical Education, University of \\ Kharazmi, Tehran, Iran
}

Received: April 18, 2018

Accepted: August 4, 2018

\begin{abstract}
Background and Purpose: Basic motor skills are the basis of advanced sports skills which should be considered in pre-school and primary school ages. The purpose of this study was to compare the effect of (child-oriented and teacher-oriented) educational methods on the motor skills development of children.

Method: This was a causal- comparative research. The statistical population of the study consisted of all kindergarten children in Kashan in 2013-2014. In this study, 78 children (49 girls and 29 boys, aged 5-7) were selected from three kindergartens by cluster sampling in two stages. They were divided into two child-centered and teacher-centered groups based on educational approach. In the teacher-centered group, the instructor conducted his activities based on a common and systematic program; whereas in the child-centered group, the center coach performed his training by giving the children the freedom of acting and the opportunity of playing. After observing and assessing the educational method of both methods, the researcher measured the basic motor skills of children. Evaluating and monitoring the motor skills of children continued for 3 weeks; including three one-hour sessions per week. The development of gross-motor -2 test of Ulrich (2000) was used to measure the basic motor skills, and multivariate analysis of variance was used for comparing between the two groups.

Results: The results showed that the child-centered learning group was superior to the teacheroriented group in the development of motor skills, but there was no difference between the two groups in terms of mobility skills ( $\mathrm{p}<0.05)$.

Conclusion: The results of the study showed that in a child-oriented educational approach, conditions are created that increase physical activity and children's play, which ultimately facilitate the development of manipulation skills in pre-school children. As a result, it can be said that adoption of a child-centered teaching method meets children's need for encouragement, opportunity to practice, and play.
\end{abstract}

Keywords: Educational methods, child-oriented and teacher-oriented training, motor skills

Citation: Kardan F, Qadiri F. Comparison of the effect of educational methods (child-oriented and teacher-oriented) on the motor skills development of children. Quarterly Journal of Child Mental Health. 2019; 6(1): 251-264.

\footnotetext{
*Corresponding author: Fatemeh Kardan, M.A. in Motor Behavior, Department of Sport Management and Motor Behavior, Faculty of Physical Education, University of Kharazmi, Tehran, Iran. 


\title{
مقايسه تأثير شيوههاى آموزشى (كودككمحور و معلممحور) بر تحول مهارتهاى حر كتى كود كان
}

\section{فاطمه كاردان"'، فرهاد قديرى'}

\author{
ا. كارشناسى ارشد رفتار حركتى، گروه مديريت و رفتار حركتى، دانشكده تربيت بدنى، دانشگاه خوارزمى، تهران، ايران

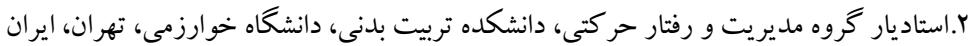

تاريخ بذيرش: س

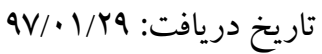

زمينه و هدف: مهارت هاى حركتى بنيادى، بائه مهارتهاى بيشرفته ورزشى است و اين مهارتها بايد در سنين بيش دبستانى و دبستانى

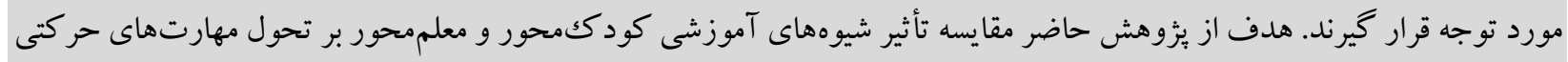
درشت كود كان بيش دبستانى بود. روش: اين يُزوهش از نوع على -مقايسـهاى اسـت. جامعه آمارى بثروهش شـامل تمامى كود كان مهد كودككهاى شـهرسـان كاشان در

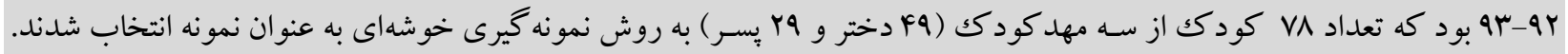

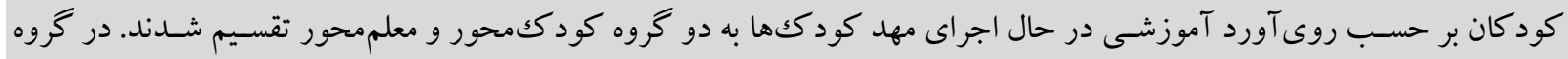

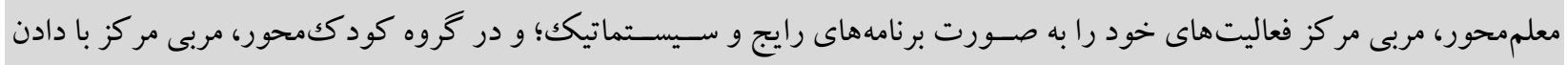

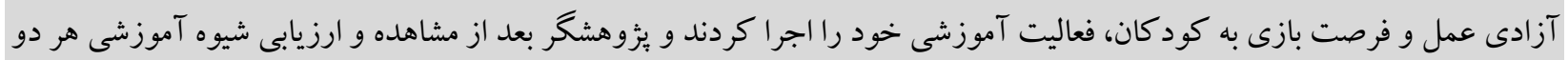

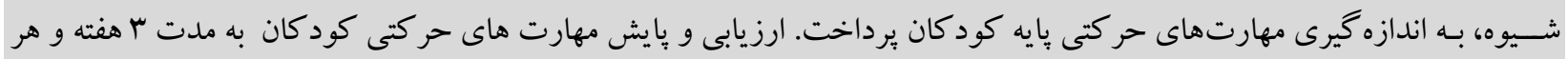

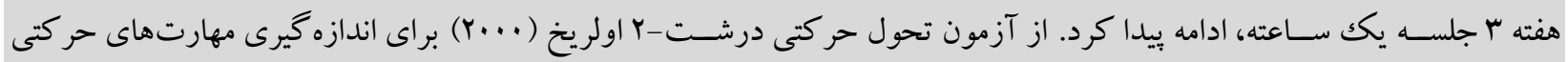

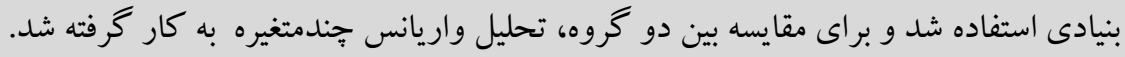

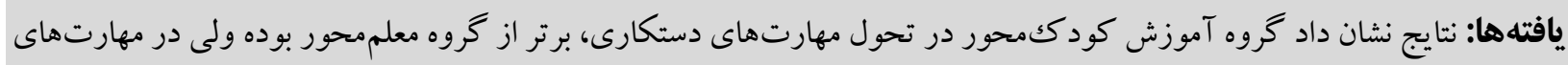

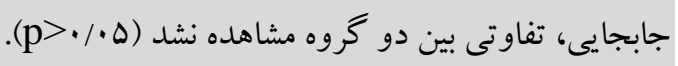
نتيجه كيرى: نتايج يزوهش نشان داد در روى آورد آموزشى كود ككمحور، شر ايطى فراهم مى شود كه منجر به افز ايش فعاليت بدنى و

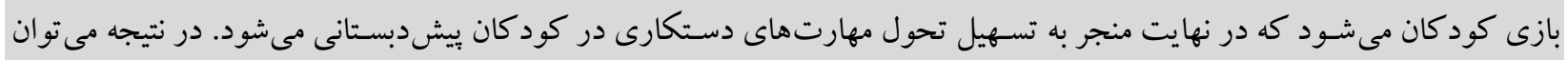

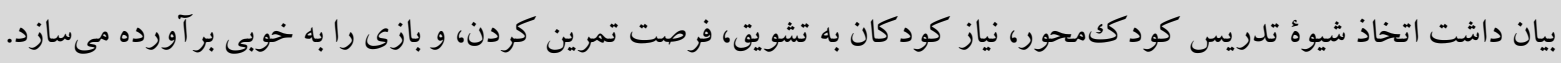
كليدوازه ها : روشهاى آموزشى، آموزش كودككمحور و معلممحور، مهارتهاى حركتى

*نويسنده مسئول: فاطمه كاردان، كارشناسى ارشد رفتار حركتى، گروه مديريت و رفتار حر كتى، دانشكده تربيت بدنى، دانشكاه خوارزمى، تهران، ايران.

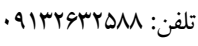


تحولى نحكر معتقـدند كه زنتيكك و محيط هر دو نقش مهمى در

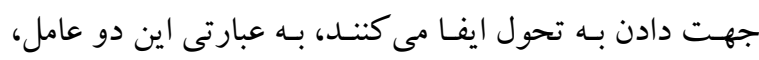

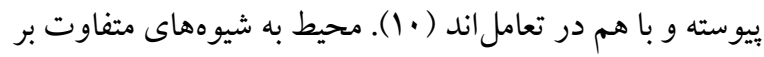

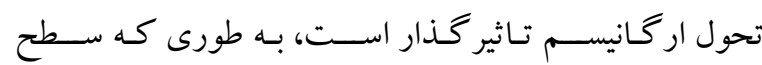
مهارت هاى اوليه و بايه بين فرزندان كشورهاى مختلف ممكن

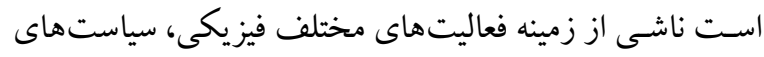

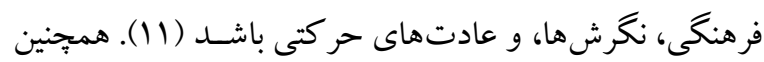

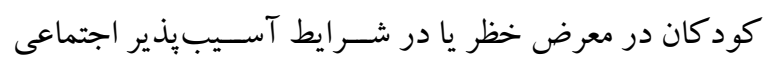

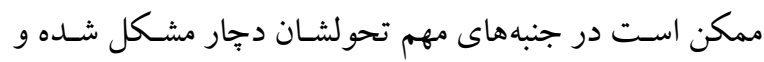

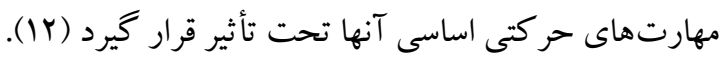

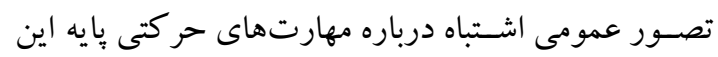

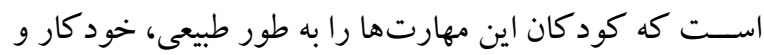

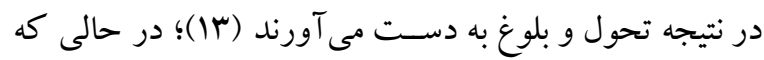

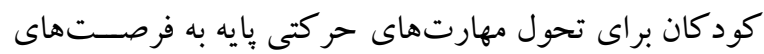
تمرينى مناسب و مشخص تحولى و دريافت يسخور اند مرتبط با مهارت نياز دارند (r). مطالعات در اين حوزه نشـان داده كه ارتباط مثبتى بين اجراى مهارتهاى حر كتى بنيادى و شـر كت

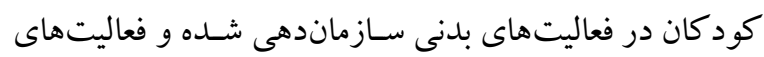
عـادى روزانه وجود دارد (F) (F). به همين علت ايجاد بسـترى مناسـب براى حركت و غنى سـازى محيط آموزشـى با ايجاد

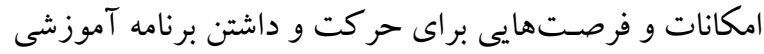

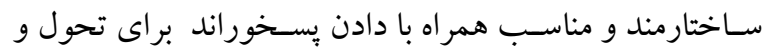

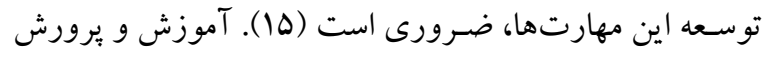
ييش از دبسـتان از طريق غنى سـازى محيطى، كود كان را قادر مى سازد كه به كسب تجارب ادار كى و ذهنى جديدى بيردازند

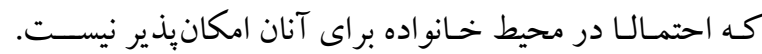
مطالعات نشــان دادهاند كه كمبود محر ككهاى محيطى و عدم امكان تجارب حسى، حر كتى، و ذهنى اثرات نامطلوب بر روند

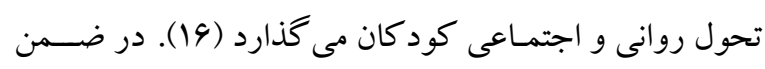
برنامههاى حر كتى در سالهاى ابتداى دبستان و ييش دبستانى از

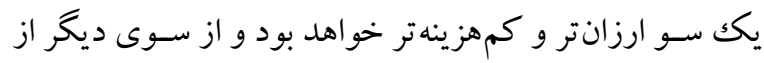

2. Gabbard

\section{مقدمه}

تحول، فرايندى بيوسـته اسـت كه همراه با تشـكيل نطفه آغاز

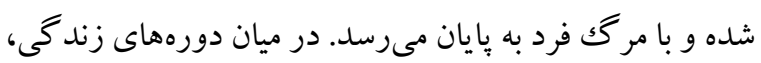
دوران كودكى، مهم ترين دوره تحول حر كتى به شـمار مى آيد

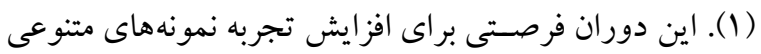

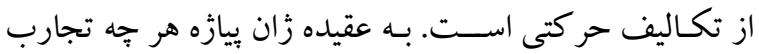
كودكك در تعـامـل با محيط متنوع تر باشــــ، وضــوح و ميزان مفاهيمى كه در او گسـترش مى يابد، بيشـتر و وسـيع تر خو اهد

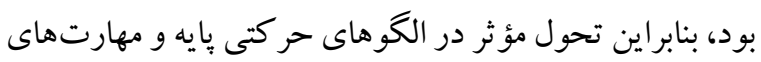

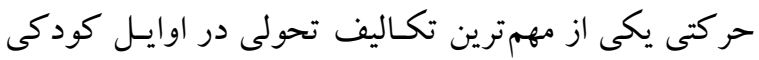

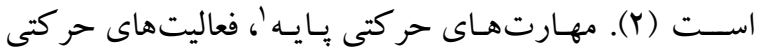

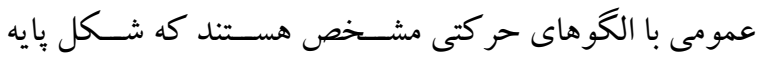
فعاليت هاى حركتى ورزشى و غيرورزشى ييشـرفته تر هستـند

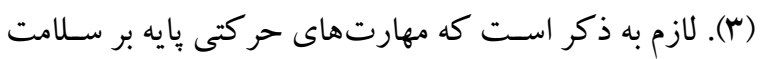

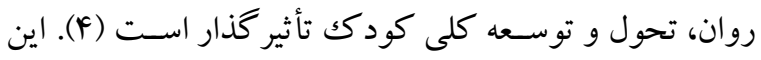
مهارتها در دو گرروه طبقهبندى شدهاند: مهارتهاى رولى جابجايى

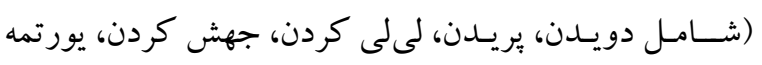
رفتن، و سـرخوردن) و مهارتهاى دسـتكارى شـى (شـامل

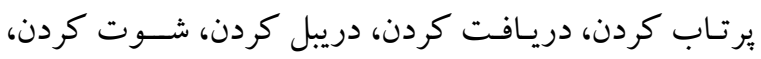
غلتاندن، و ضـربه زدن) (ه). مطالعات زيادى از جمله يزوهش

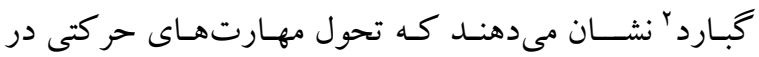
سالهاى اوليه كودكى مقدمهاى براى تحول حر كتى ييشرفته تر،

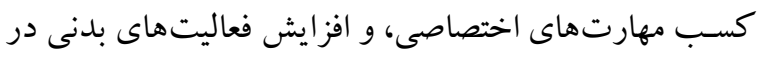
نوجوانى و جو انى اسـت (9)؛ بنابر اين عدم دسـيابى به مر احل بيشـفته در اجراى اين مهارتها مشـكلاتى رانه تنها در تحول مهارتهاى ثانويه، كه در تحول مهارتهاى مذكور در ســنين

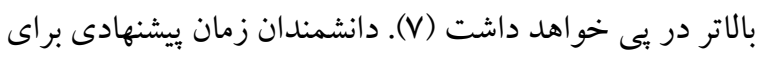

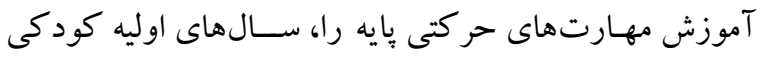

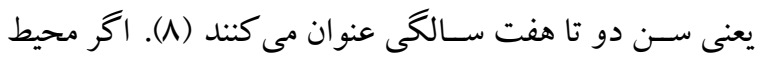

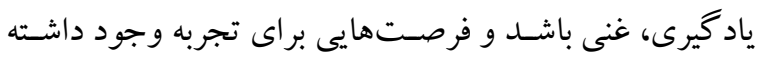

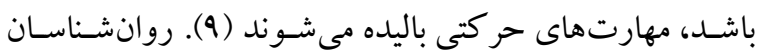

1. Fundamental motor skills 
تجربيات تصـويرى خو اهد شــــ (r/Y). به اين ترتيب بازى در

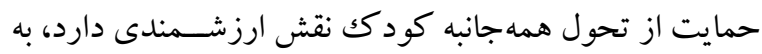

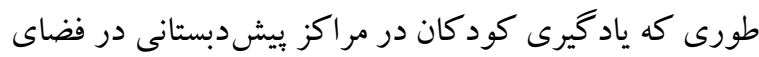

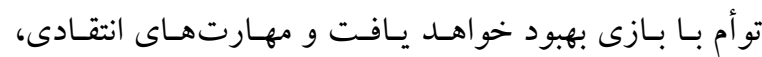
شناختى، و اجتماعى آنها تحول جشمخيرى خو اهد يافت (YF).

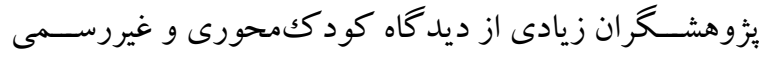

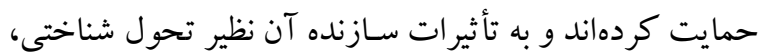

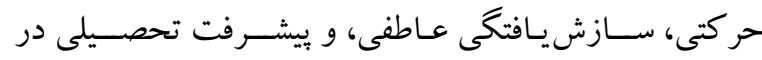

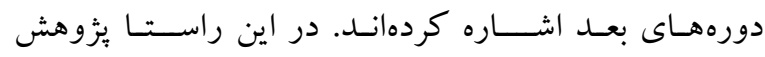
شـــاهين ســاكك، ســاكك و تيزلشـــاهين (19) بر روى آورد كودككمحور آموزش بيشدبســتانى در راســاى تغيير رفتار

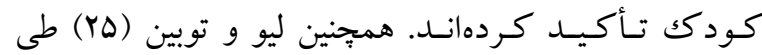
مطسالعـاى در مهـدكودككهـاى جين اذعـان كردنـــ تمرين

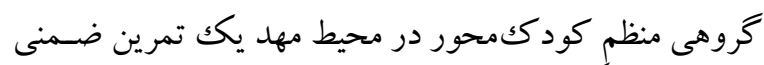
غيرمستقيم اسـت كه معانى و لذتهاى متمايز را توليد مى كند

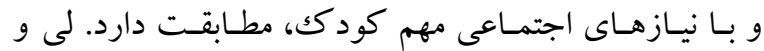
هـمكـاران (Yq) نيز بر يـاد كيرى فعـال مبتنى بر روى آورد

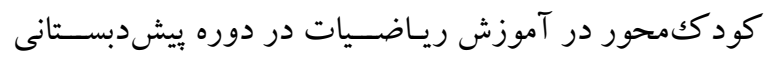

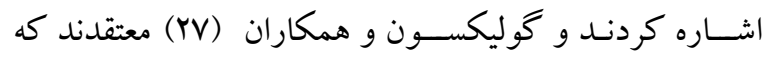
ترويج برنـامـه درسـى كودككمحور منجر بـه ارتقاء ســطوح خلاقيت كود كان در دوره بيشدبستانى خواهد شد. نتايج مشابه

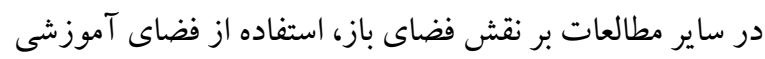

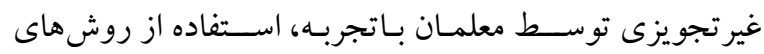

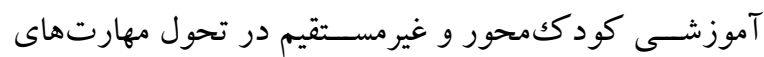

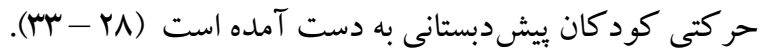
هسـتى، جانسـون و روديسـل (MF) در مطالعه خود نتيجه

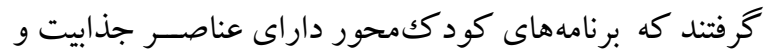
تاز گى بوده و بـا مهارت هاى كود كان مطابقت دارد و در عين

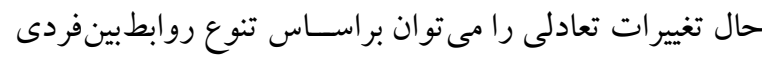

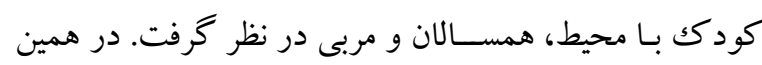
راسـتـا كبرى و رحمتى (ه) طى مطـالعهاى اذعان كردند كه آموزش بازىدرمانى مبتى بر روى آورد شــناختى -رفتارى به
انزواى اجتمـاعى كودكـان بهنجـار و كودكـان داراى اختلـال

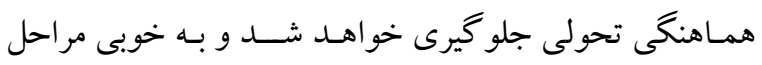
تحول خود راطى خواهند كرد (IV). امروزه برنامه هاى مر اكز ييشدبسـتانى تا حدود بسـيار كسـتر دهاى به وســيله عقايد و نظريات جارى در زمينه تحول كودكك حمايت شــده و از آنها

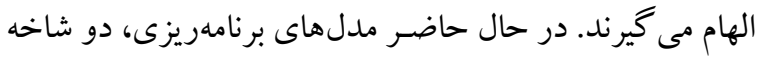
را در بر مى گيرند: مدل هاى رسمىى مهارت محور كه اسـاسـاً در

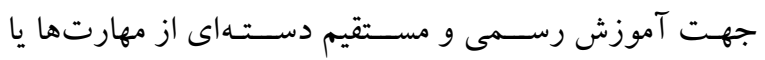
اطلاعات ويزه به خصوص در سطوح خواندن، حساب كردن، و مهارتهاى كلامى را شــامل مى شــوند. اين كونه برنامهها، بيشتر از توجه به اصالت كودكى و كودكمتحورى، معلمنكر يا موضـوع محورند. شـاخه ديخر، مدلهاى غير رسمى هستند كه

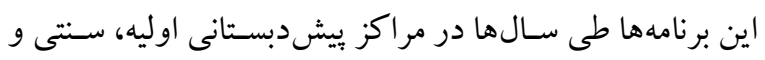
كود ككمحور بـه صـورت غير رســمى براى تمـامى كود كان

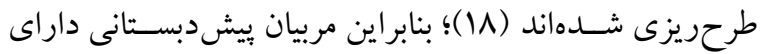

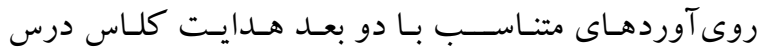
كود ككمحور و معلممحور هســتـــ كـه عمـدتـاً تحـت تـأثير

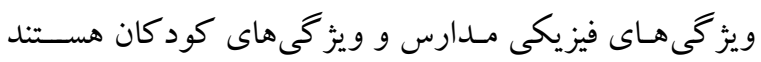

يـك برنـامـه مناسـبـ در دوره بيش از دبســان، تجارب محر كك براى تحول ذهنى، جسـمى، اجتمـاعى، حر كتى، و

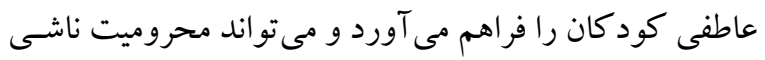

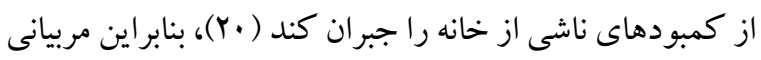

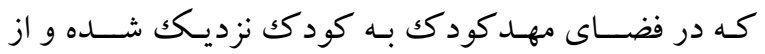
خودمختـارى كود كك حمـايـت مى كننـــ در بايان ســال دامنه واز كان و خودتنظيمى كودكى ارتقاء خواهد يافت ( (Y). همان طور كـه مىدانيم روش آموزش و برورش در دوره يِش از

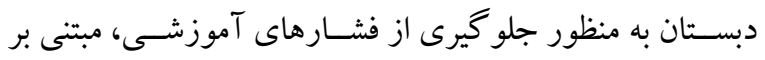
روش بازى اسـت (YY)؛ يعنى بايد بر اســاس بازى و فعاليت

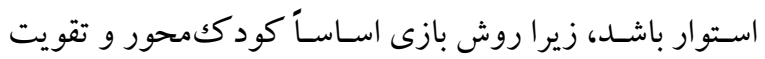
كننده نيازهاى فردى، تو انيىها و علايق اسـت. بازى همجنين

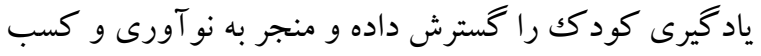




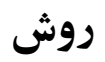

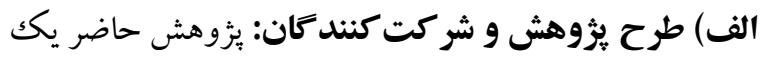

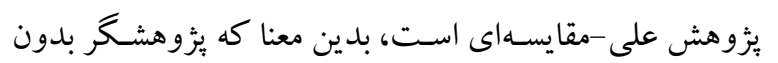

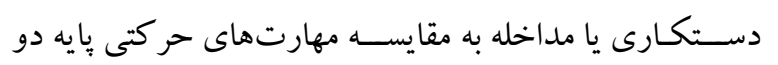

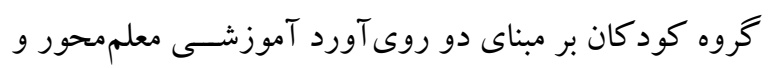

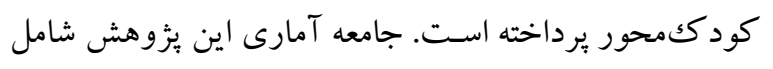
كود كان مراكز بيشدبستانى شهر كاشان در سال بهو- بهو بود.

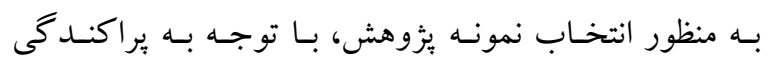

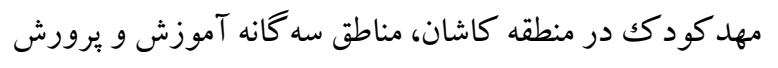

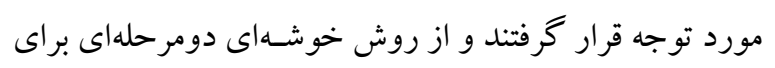

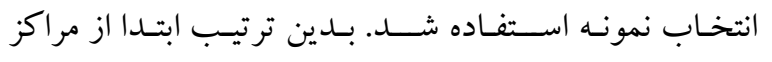

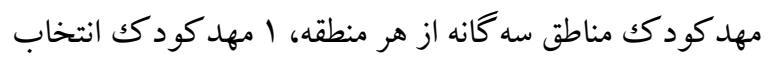

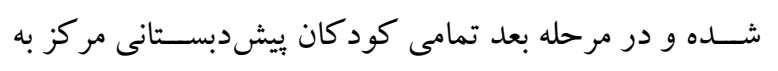

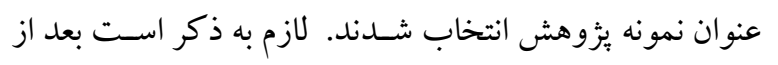

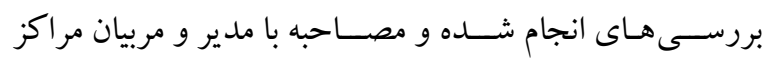
مشـخص شـد كه روى آورد آموزشسى غالب در بيشـتر مراكز

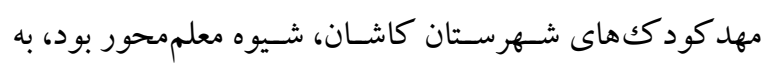

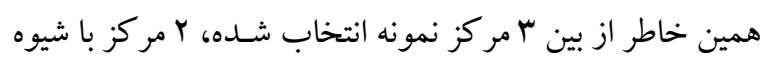

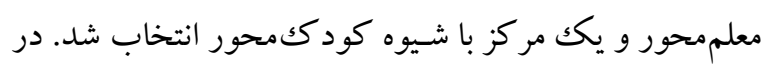

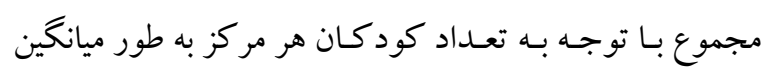

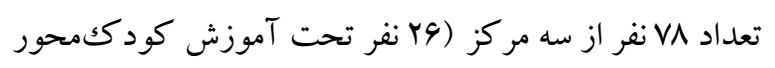

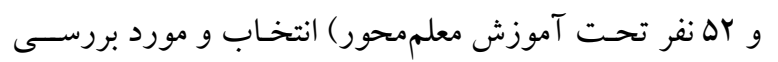

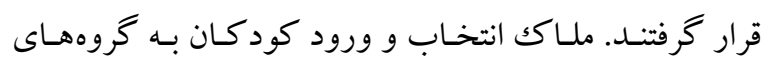

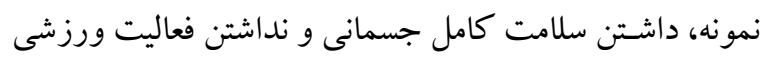
خاص بود. همجنين از بين كود كان هر مهل تنها كود كانى كه داني

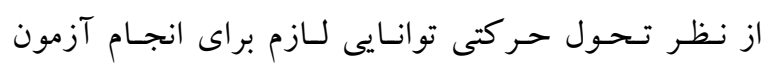

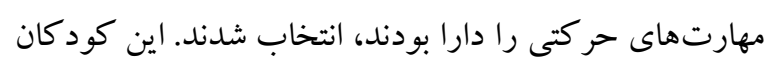
در دامنه سنى هو و سال قرار داشتند كه از اين مقدار هو هو دختر

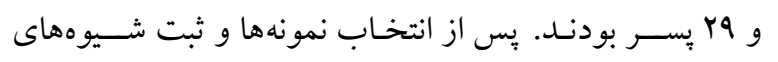

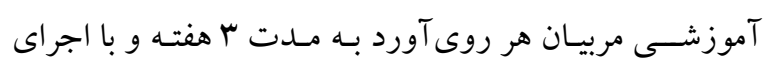
آزمون تحول حر كتى درشت اولريخ اجرا شد.
صورت آموزش غيرمستقيم؛ در كود كان 4-9 ساله بر كاهش

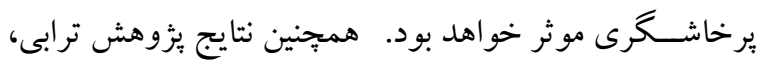

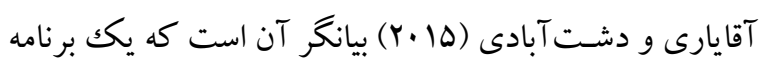

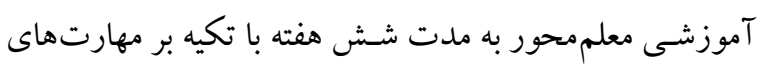
دسـكارى و جابجايى قادر اسـت آثار مفيدى بر تو توانايىهاى

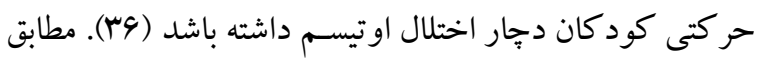

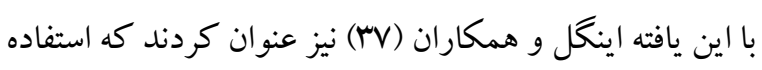

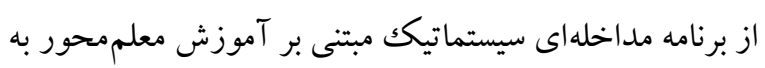
به:بود مهارت حر كتى كو دكان منجر شده است.

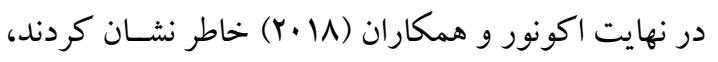
جهت دستيابى به سطوح بالاى مهارت حر كتى سن، جنس، و و

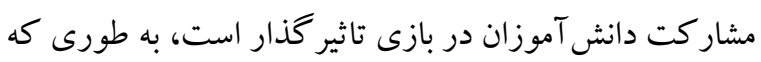

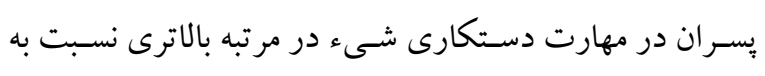

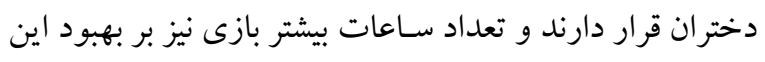

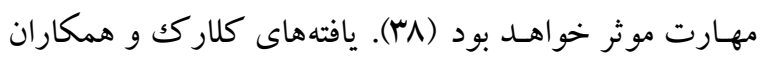

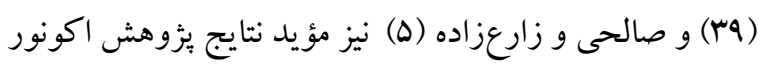

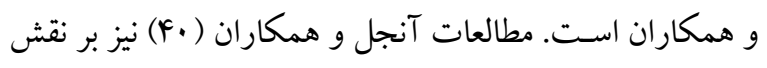

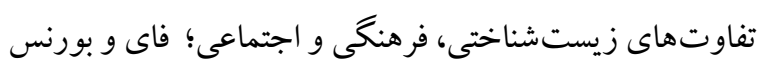

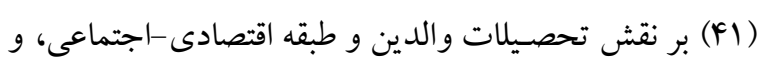

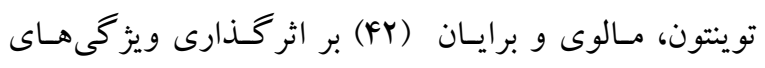

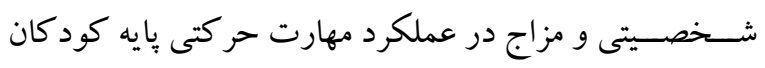

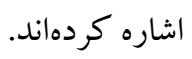
بـا توجه به نظريات فوق و با توجه به اين موضسـوع كه در

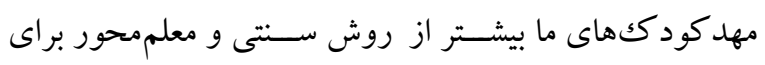

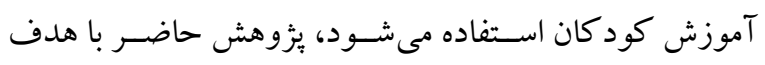

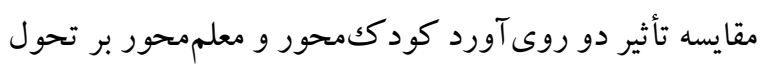
حر كتى كود كان مقطع بيشدبستانى انجام شده است تا به ائ اين

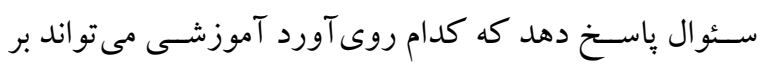
تحول حر كتى كود كان تأثير بيشترى داشته باشد؟ دوى آرد آمونى 


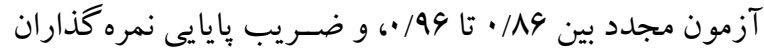

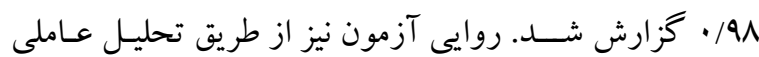

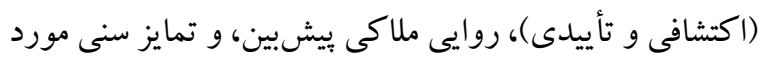

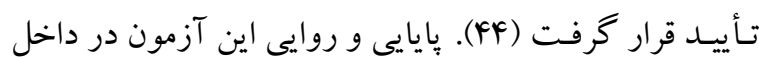
كشـور نيز توسط ارشـم، سـرابندى و سنائى (YN) محاسبه شد.

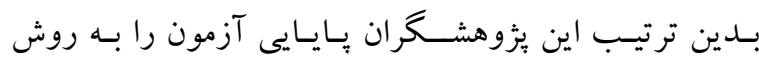

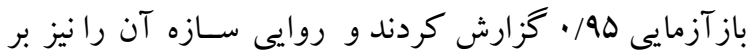

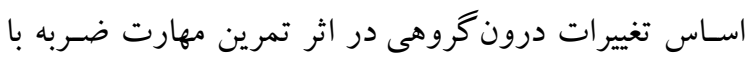

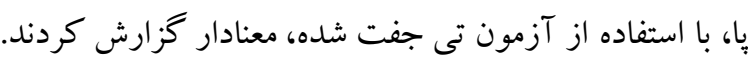
ج) روش اجرا: للازم بـه ذكر اســت كـه هيج گونـه برنـامـهـ

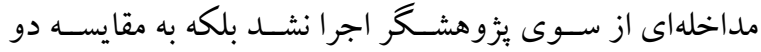
روى آورد در حـال اجرا توســط مربيـان مراكز مهدكود ككها يرداخته شده است. اين دو روى آورد در بخش مقدمه اين مقاله

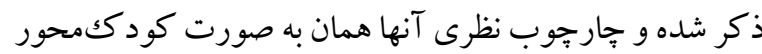
و معلممحور اسـت. روى آورد معلممحور، شـيوه غالب بيشـتر مراكز آموزشى كذشته و حال است كه به روش سنتى معروف

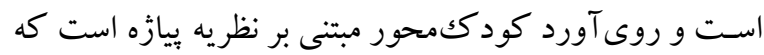

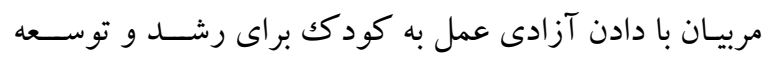
همهجانبه كودك اهميت بيشترى قائل اند و كود كك با تعامل با ترائ محيط اطراف خود به كســب تجربه مى يردازد (Y، 11 و 19). در اين مطالعه بعد از كسب مجوزهاى للازم، بر اساس روى آورد آموزشى در حال اجراى مربيان هر مهدكودكى، كود كان به دو كروه آموزشى كودككمحور و معلممحور تقسيم شدند. بدين هورين ترتيب بعد از مصاحبه با مدير، مربيان و كمككمربيان و همجنين مشــاهــده دو روش آموزشـى مربيـان در ب مهـدكودك و

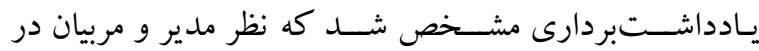

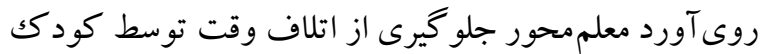
بود به كونهاى كه شـر ايط بازى و آزادى عمل كودك بس بسيار

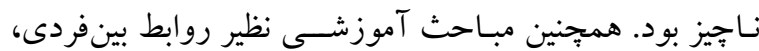
علوم، بهداشت، ايمنى و قصه خوانى و نقاشى به طور مستقيم و
ب) (بزار ا ـ مشـاهله و ثبت /طلاعات: ابزار اندازهگيرى براى تعيين نوع آموزش مهد كودككها بر اسـاس دو روى آورد كود ككمحور

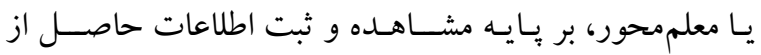

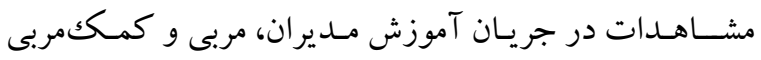
مراكز ييشدبســــانى بود. اين مشـــــــات در قالب مجموعه سـوالات طبقهبندى شده و ملدون بر اساس سئو الات يزوهش به

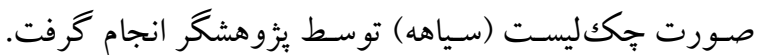

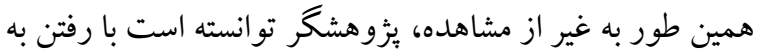
هر يـك از مراكز ييشدبســتانى با كار كنان آن مؤسـســهـها،

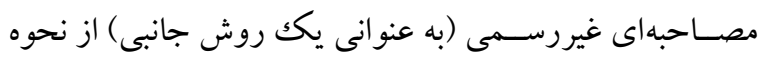

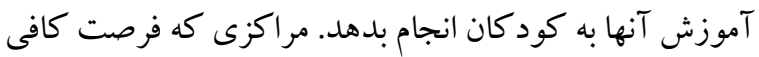
بـهـ كود كك براى بـازى و فعـاليـت ارائه مى كردند و برنامههاى

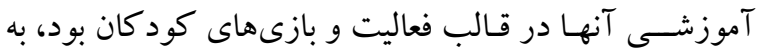
عنوان كودككمحور در نظر كرفته شدند.

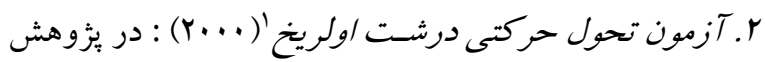
حـاضــر براى ارزيـابى تحول مهـارتهـاى حر كتى درشــت

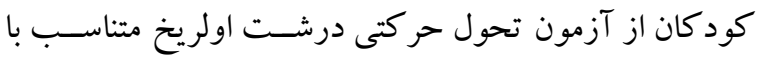

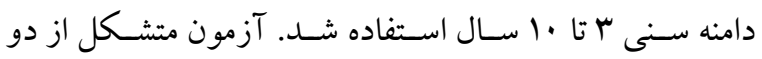

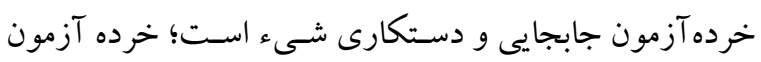
جابجايى متشكل از شش مهارت بنيادى دويدن، يورتمه رفتن،

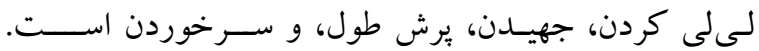
خردها آزمون دسـتكارى شــامل ضـربه به توب ثابت با باتون، دريبل درجا، دريافت كردن، ضربه با با، بر تاب از بالاى شانه، و

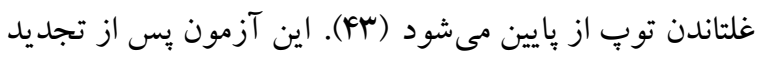

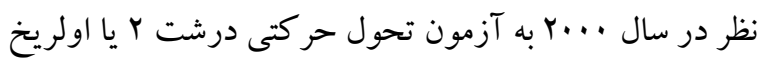
مشـــ.... آزمون براى كود كان آمريكايى توسط اولريخ گز اش شد. در اين گزارش ضريب همسانى درونى آزمون براى دختران سوه/ .

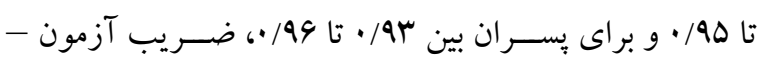

1. Test of Gross Motor Development Olrich (TGMD2) 
تكليفى كه بايد كود كك انجام دهد بر اســاس دسـتور العمل به روشسنى توضسيح داده شد و اجراى مهارت صحيح نمايش داده شــ. هر كودك اجازه داشت يكك كوشش تمرينى انجام دهد

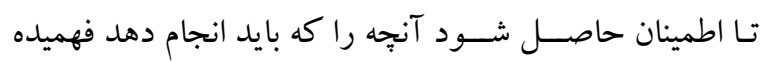
اسـت. در صـورتى كه به نظر مىرسـيد كودك نحوه اجرا را

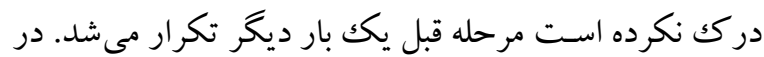
يايان كود كك مهارت مربوط را طى دو كوشـش انجام مىداد.

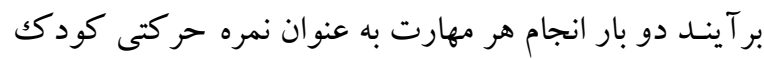

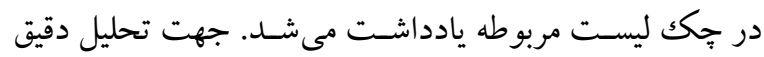
حركات كود كك در گويسهــاى مورد نظر بـا دوربين از زاويـهـ جانبى فيلمبردارى انجام شــــ. در اين آزمون براى هر مهارت

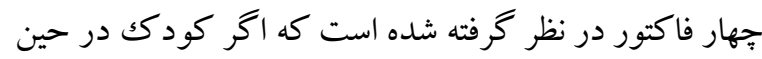

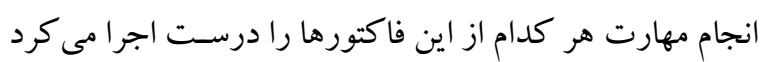
نمره يك و در صسورت اجراى غلطف نمره صـفر مى گرفت؛

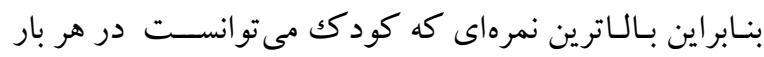
اجراى مهارت كسب كند جهار و كمترين آن صفر بوده است. لازم به ذكر است تمامى ملاحظات اخلاقى در اين مطالعه به دقت مورد توجه قرار گرفت و در بايان به منظور بررسى دادهها

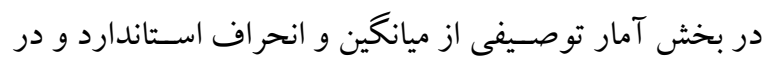
بخش آمار اسـتنباطى براى مقايسـه دو گرووه از آزمون تحليل واريانس جندمتغيره با استـفاده از نرمافزار آمارى 19 19 استفاده شد.

يافته ها

در جدول ا، شـاخص هاى توصيفى خردهمهارتهاى جابجايى

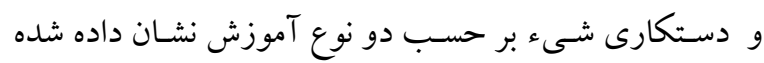

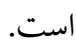

جهره به جهره، بود. باوجود آنكه طبق ضوابط مهدكودككها، خانه بازى در مهد مهيا بود ولى مربيان و مدير مهد معتقد بودند كـه بـازى كود كان در خانه بازى اتلاف وقت اســت، بنابراين

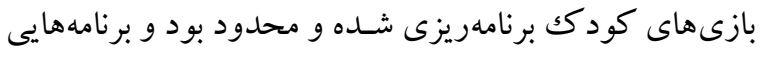
نظير تئاتر، موســيقى، و آموزش زبان جايكزين بازى كود كان

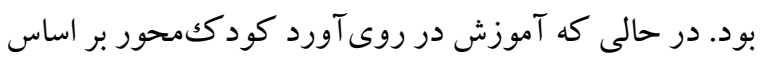
دادن آزادى عمل به كودكك و مبتنى بر بازى بود.بدين ترتيب

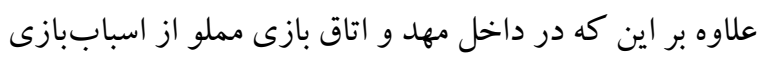
و وسـايل كمكك آموزشسى بود در فضساى باز و حياط مهد نيز وســايـل بازى مهيا بود. در اين مهد كه بر اســاس روى آورد

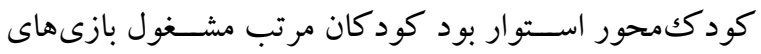

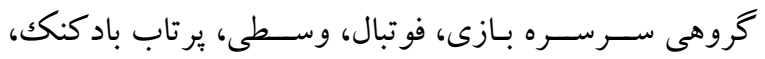

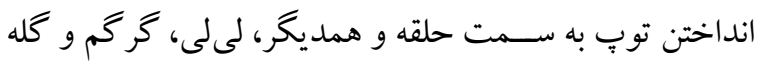
مىبرم، مسـابقهى دو و نظاير آن در فضـاى باز بودند. همجِنين

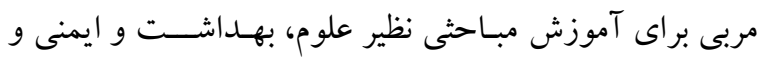

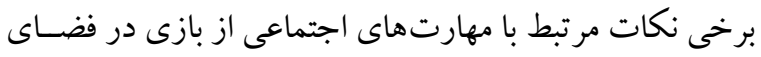
بـاز و اتـاق بـازى اســفــاده مى كرد و كودكـان جهـت تمرين مهارتها به بازى گروهى مشغول مى شدند. در بايان مشاهدات

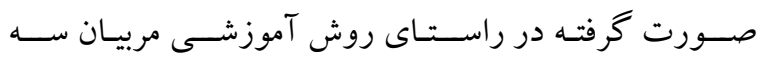

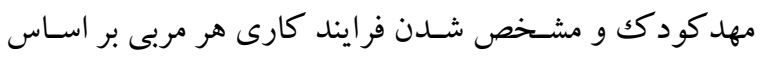

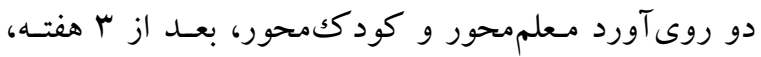

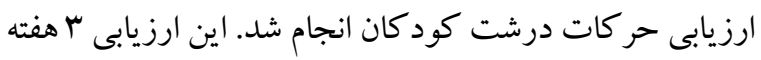

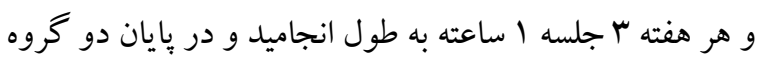
از كود كان با يكديخر مقايسه شدند.

بر اسـاس دستور العمل آزمون تحول حر كتى درشت، ييش از آزمون مشخصات كودك در فرم نمره كذارى ثبت، شرايط

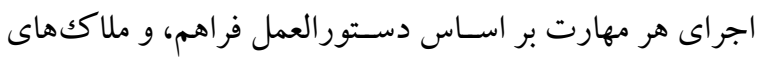

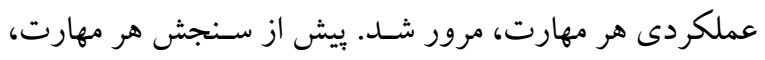


جدول ا: شاخصهاى توصيفى خرده مهارتهاى جابجايى و دستكارى شىء در كروههاى آموزشى كودكىمحور و معلممحور

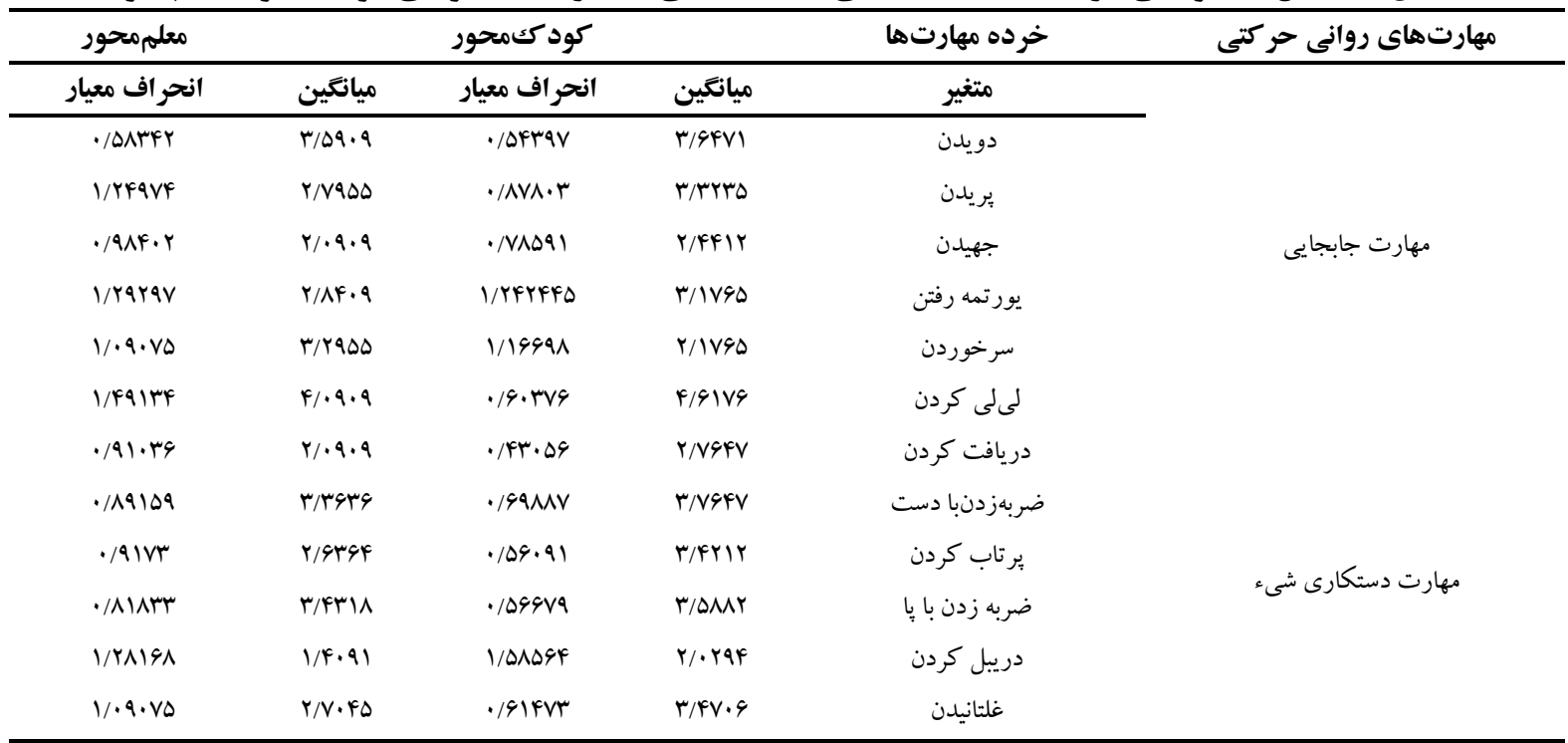

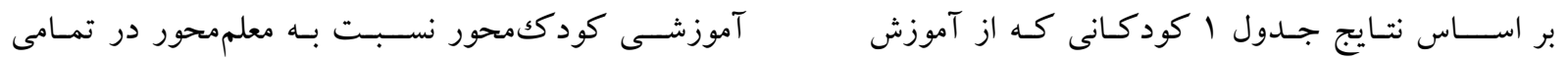
مؤلفه هاى دسـتكارى شـىء بالاتر اسـت. در ادامه نتايج آزمون

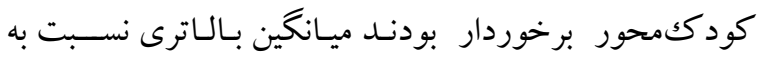
تحليل واريانس جندمتغيرى در جدول ب ارايه شده است.

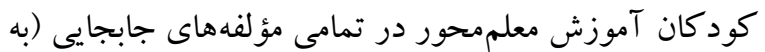

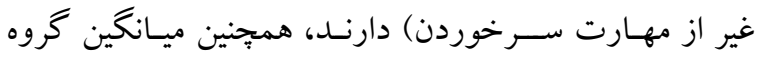

جدول r: نتايج آزمونهاى معنادارى تحليل واريانس حندمتغيرى ( مانكوا ) بر روى ميانكينهاى مؤلفهاى تحول حر كتى

\begin{tabular}{|c|c|c|c|c|c|c|}
\hline مجذور اتا & سطح معنادارى & $\mathbf{F}$ & خطال & فرضيه Df & مقدار & ن ام آزمون \\
\hline$\cdot / 4 \Lambda$ & $\cdot \cdots$ & $0 / \cdot 1$ & 90 & Ir & $\cdot / 4 A$ & آزمون اثر ييلايى \\
\hline$\cdot / 4 \Lambda$ & $\cdot / \cdots$ & $0 / \cdot 1$ & 90 & ir & $\cdot / 81$ & آزمون لامبداى ويلكز \\
\hline$\cdot / 4 \Lambda$ & $\cdot / \cdots$ & $0 / \cdot 1$ & 90 & ir & $\cdot / 9 r$ & آزمون اثر هتلينكَ \\
\hline$\cdot / 4 \wedge$ & $\cdot / \cdots$ & $\Delta / \cdot 1$ & 90 & ir &.$/ 9 r$ & آزمون بزركترين ريشه رى \\
\hline
\end{tabular}

تفاوت بين دو كروه با توجه به متغيرهاى وابســته در مجموع معنادار است و ميزان اين تفاوت تقريباً \&A/ • است. يعنى تقريباً FA درصد از واريانس مربوط به اختلاف بين دو گروه در تأثير متقابل متغيرهاى وابسـته اسـت. حال براى اينكه بررسى كنيم اين تفـاوت در كدام زيرمقياسهاسـت اثرات بين آزمودنىها كزارش مىشود (جدول
بر اسـاس نتايج بدست آمده در جدول r شاخص لامبداى ويلكز كه اثر نوع كروه بر تر كيب خطى متغير وابسته را نشان مىدهد معنادار اسـت ( كـه حـداقـل بين يكى از زيرمقيـاسهـــ تحول حركتى در كودكـان بـا دو روى آورد آموزشــى تفـاوت وجود دارد. مجـذور اتـا (كـه در واقع مجـذور ضــريـبـ همبســــى بين متغيرهاى وابسته و عضسويت گروهى است) نشان مى دهد كه 
جدول "ّ: اثرات بين آزمودنى ها در مولفههاى مهارتهاى حركتى

\begin{tabular}{|c|c|c|c|c|c|c|c|}
\hline ضرايب اقا & سطح معنادارى & $\mathbf{F}$ & ميانكين مجذورات & درجه آزادى & مجموع مجذورات & مهارتهاى حركتى & خرده آزمون \\
\hline$\% r$ & .194 & $\cdot / 1 \Lambda$ & .1 .9 & 1 & .1 .4 & دويدن & \multirow{4}{*}{ جارتهاى } \\
\hline.$/ . q$ & $\cdot / \cdot \Delta$ & $r / v \Delta$ & D/rr & 1 & D/r & لى لى كردن & \\
\hline .1 .0 & $\cdot / \cdot r$ & $r / r q$ & $r / r \Delta$ & 1 & $\Delta / \mu F$ & يريدن & \\
\hline.$/ \cdot r$ &.$/ .9$ & $r / M$ & $r / 19$ & 1 & r/ro & جهيدن & \\
\hline.$/ .1$ & $\cdot / r \Delta$ & 1/N & $r F / \cdot 1$ & 1 & $r / 19$ & يور تمهرفتن & \multirow{8}{*}{ دستكارى شىء } \\
\hline$\cdot / r$. &.$\cdots$ & $1 / / 99$ & $\Lambda / v$ & 1 & $r F / \cdot 1$ & سرخوردن & \\
\hline$\cdot / \mathrm{VV}$ & $\% \ldots$ & $1 D / A F$ & $r / \cdot \Lambda$ & 1 & $\Lambda / v$ & دريافت كردن & \\
\hline$\cdot / \cdot \Delta$ & $\cdot / \cdot r$ & $4 / 99$ & Ir/Fr & 1 & $\mu / \cdot \Lambda$ & ضربه زدن & \\
\hline$\cdot|r|$ & $\cdot / \cdots$ & $r \cdot / r V$ & $11 / r \Delta$ & 1 & $I Y / F Y$ & ير تاب كردن & \\
\hline$\cdot / 10$ & $\cdot / \cdots$ & $\mid r / F F$ & $\cdot 144$ & 1 & $11 / r \Delta$ & غلتاندن & \\
\hline.$/ .1$ & . & . /Ar & $\mathrm{V} / \mathrm{\mu} \Lambda$ & 1 & $\cdot / 44$ & ضربهزدن بإيا & \\
\hline.$/ .4$ & .1 .9 & $r / 90$ & & 1 & $\mathrm{~V} / \mathrm{r \Lambda}$ & دريبل كردن & \\
\hline
\end{tabular}

همكاران (Y))، كاديمه و همكاران (YI)، هسـتى، جانسـون و روديسل (YY)، و ارشم، سرابندى و سنائى (YN)، است. آنها نيز

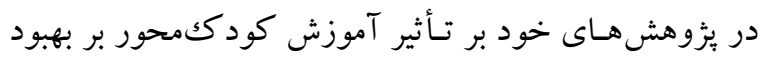
مهارتهاى حركتى كود كان در مقطع بيش دبســتانى اشــاره

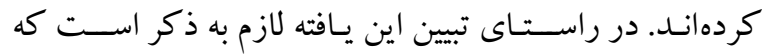
روى آورد كودككمحور و روشهـاى تدريس مرتبط با آن در مقايسه با روى آورد معلم محور و آموزش سنتى، بيشتر به علايق

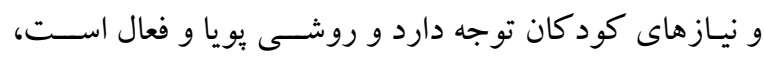

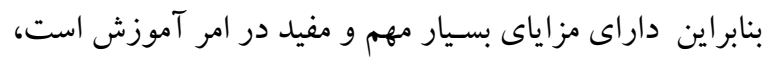
فعـاليـتهاى انجام شـــه با اين روش بيشــتر مبتنى بر بازى و

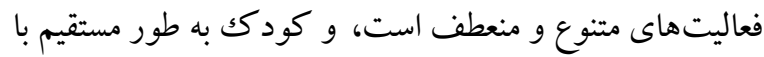
مطالب و ياد گيرىهاى مورد نظر كه دلخو اه كودكى نيز هست

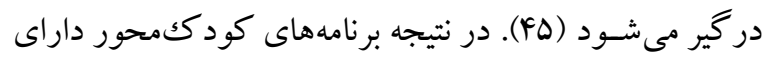

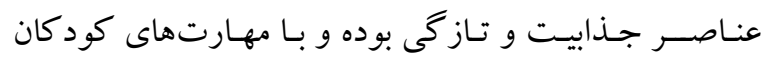

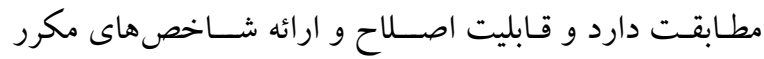
ييشــــت و بهبود مهارت هاى حر كتى بايه را دارا اســت و در

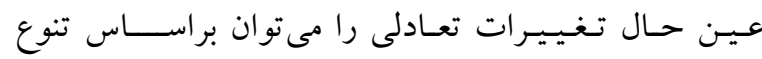

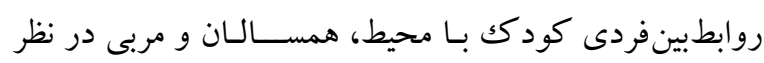

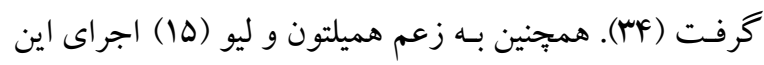

همانطور كه در جدول ب مشــاهده مى شــود بين ميانخين نمرات زيرمقيـاسهـاى بريــن، ســرخوردن، دريـافت كردن، ضــربـهزدن، برتابكردن، و غلتاندن تفاوت معنادارى وجود

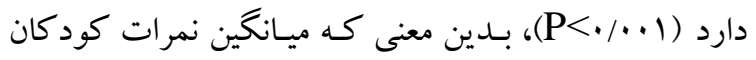

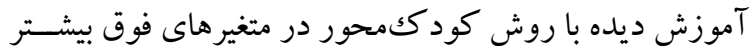
از كود كان با روى آورد معلممحور اسـته. اما در سـاير زير مقيـاسهـا يعنى دويـدن، لىلى كردن، جهيدن، يورتمه رفتن،

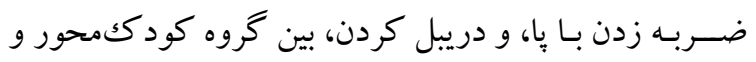

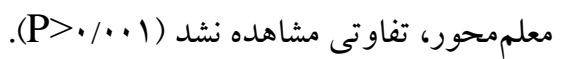

\section{بحث و نتيجه كيرى}

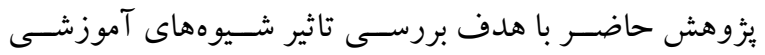
كودككمحور و معلممحور بر تحول مهـارتهـاى حركتى كود كان صسورت گرفت. نتايج اين يزوهش نشان داد كه شيوه آموزش كودككمحور بر تحول مهارتهاى دستكارى كودكان

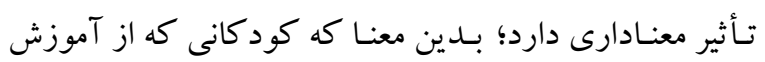

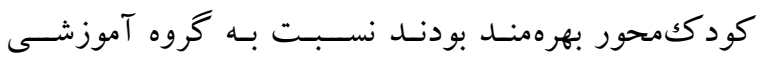
معلمححور در مهارتهاى حر كتى دسـتكارى، عملكرد بهترى

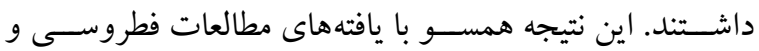


به تفاوت دو روى آورد آموزشسى معلممحور و كودككمحور در بهبود مهارتهـاى شــناختى، رفتارى، و حر كتى كود كان

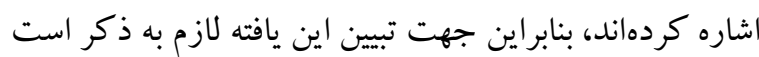

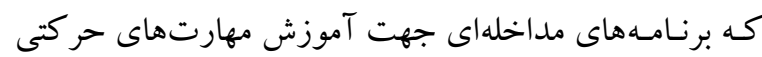
بايه، تحت تأثير ويز گیىهاى فيزيكى مدارس و كود كان (F4) و همجنين مبتنى بر سابقه و تجربه مربى هستند است؛ بدين معنا كه مربيان مبتدى اكثراً از آموزش مسـتقيم و معلممحور جهت بهبود مهارتهـاى حر كتى اســفــاده خو اهنــ كرد و مربيـان باتجربه تر از روش آموزشـى غيرمسـتقيم مبتنى بر روى آورد

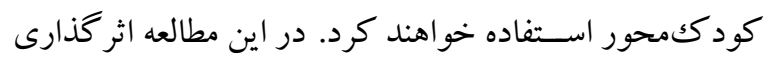

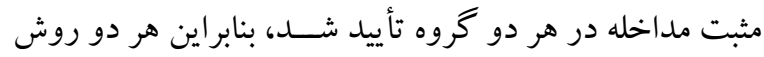

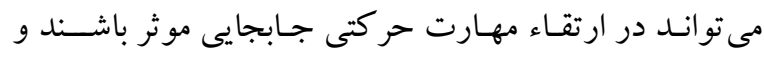

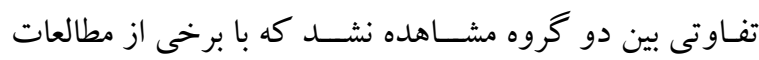
همسو است (Yr). البته جِنانجه امكانات ورزشى و وسايل بازى

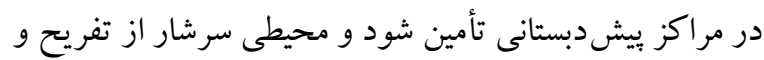

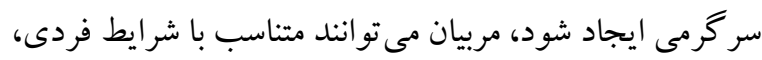

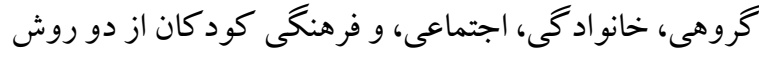

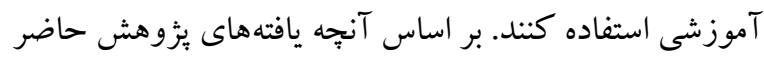

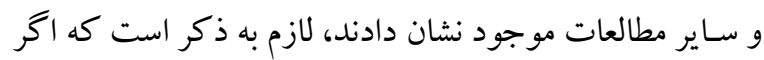
جـهـ مــاخلـات مهـارتهـاى حركتى اغلـب موجـب بهبود مهارتهاى حركتى بايه در دوران بيشدبستانى مىشـود، ولى ميز ان موفقيت كود كان متفاوت است. اين تفاوت را مى توان به به

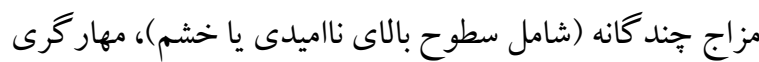

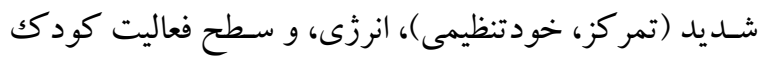
مرتبط دانست؛ بنابر اين نتايج اغلب تحت تاثير عوامل شناختى،

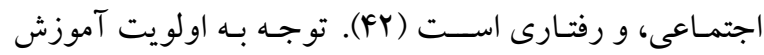
غيرمستقيم نسبت به آموزش مستقيم در دوره بيش دوبستان و نظر

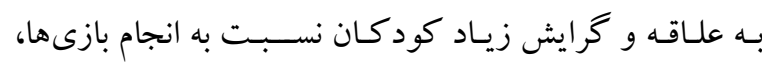
كود كان مهارتهاى مورد نظر را در قالب بازىهاى گوناگون

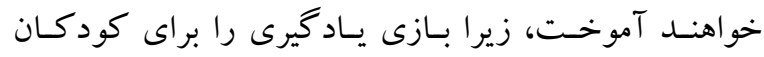

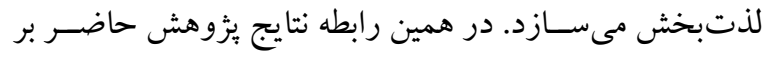
اهميت فراهم سـاختن تجارب حر كتى متنوع و متناسـبـ براى
كونه برنامه هاى مداخلهاى اثر درمانى داشته و منجر به تحول و

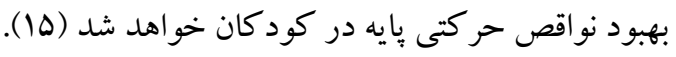
نتـايج يزوهش حاضــر با يافتهاى وزينى طاهر و همكاران

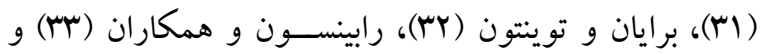

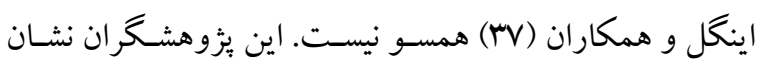
دادنــ كودكـانى كـه از آموزش معلممحور برخوردار بودنســ نسـبـت بـه كودكـانى كه از آموزش كودككمحور برخوردار بودند در مهارت دستكارى شىء، برترى داشتند. در تبيين اين

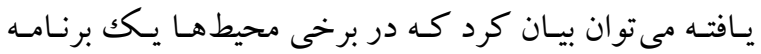
مداخلهاى سـيسـتماتيكك مبتنى بر آموزش معلممحور مى تواند

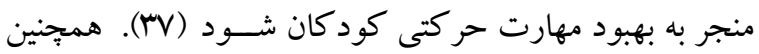
جهت دستيابى به سطوح بالاى مهارت حر كتى سن، جنس، و

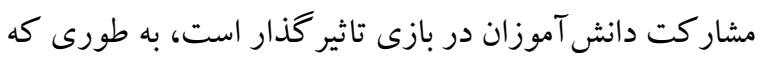

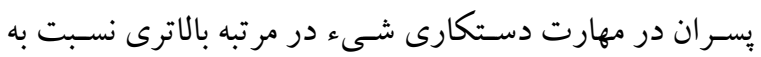
دختران قرار دارند و تعداد سـاعات بيشتر بازى نيز بر بهبود اين

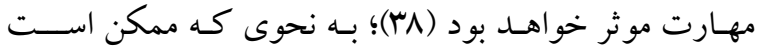
دختران در فضايى كه توسط معلم هدايت شده باشد عملكرد بهترى از خود نشــان خواهنـد داد. مطـالعـات موجود نيز تأثير

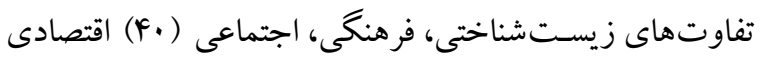

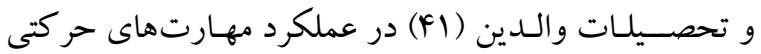

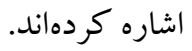
يكى ديكر از يافته هاى بثزوهش حاضر عدم وجود تفاوت

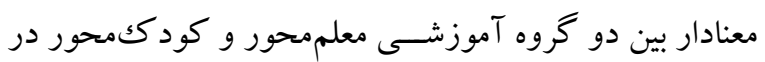
مهارت جـابجايى اســت. اين يافته با نتايج مطالعه حسـين و و

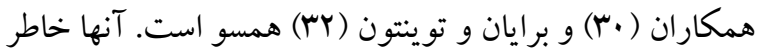
نشـان كردند كه مداخلات ورزشى ساختارمند و غير ساختارمند در دو فضـاى باز و كلاس و ارائه تجهيزات براى بازى توسـط

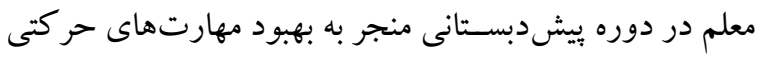

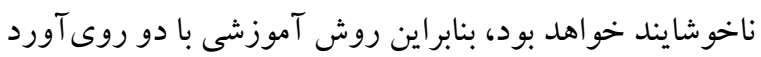
معلممحور و كودككمحور نتايج مشـابهى در يى خوز اهد داشت. يافته به دست آمده با يزوهش هميلتون و ليو (ها)، ليو و توبين

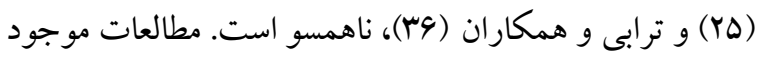


طبقه اجتماعى -اقتصـادى كودكى را در نظر بخيرند. از آنجايى

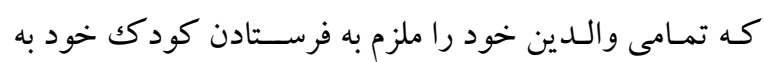

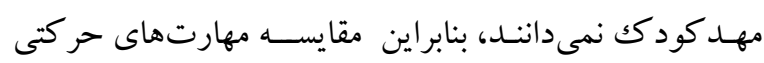

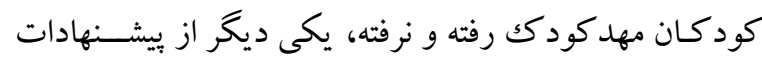

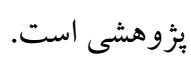

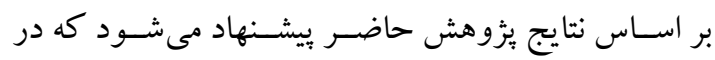
راســـاى بهبود مهـارتهـاى حر كتى، مربيـان بهتر اســت از بازىهاى بومى و محلى بيشتر استفاده كنند. در نهايت معطوف مربـ

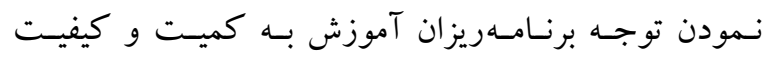

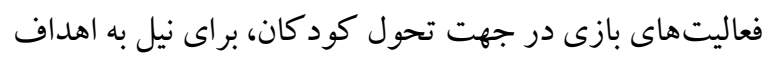
آموزشى، و ايجاد يكك تفكر صسحيح در اهميت دادن به بازى باري دري

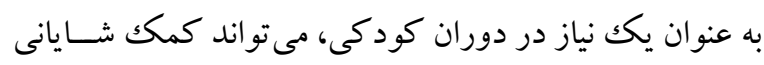
در تدريس دروس و بهرهورى آموزشى ايجاد كند.

تشكر و قدردانى: اين يُزوهش به صسورت مستقل با شماره مجوز ه. ه

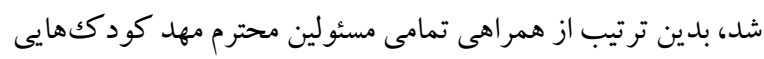

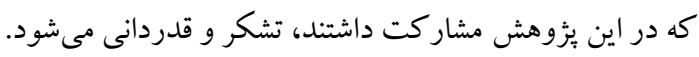
تضاد منافع: با توجه به اينكه اين يزوهش تحت حمايت مالى هيج

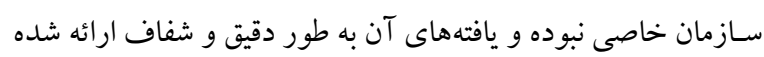
است، هيج گونه تضاد منافع وجود ندارد.
تحول همه جانبه براى هر كود كك تاكيد دارد. للازم به ذكر است

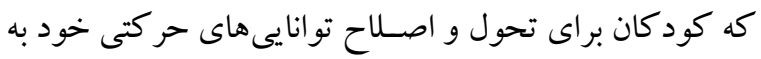

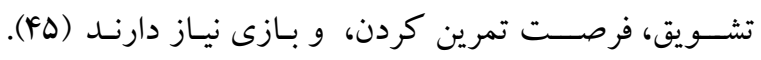

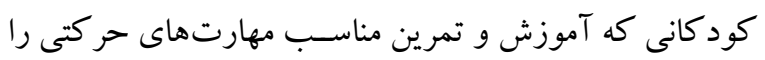

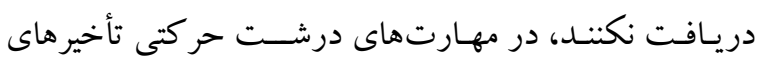
تحولى را نشــان مىدهنـد (Yr) و متـأسـفــانـه همـه كود كان فرصـتهاى برابر براى شـركت در فعاليتهاى بدنى و تحول

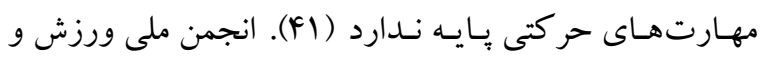

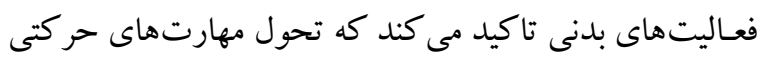

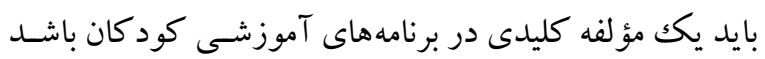
(FV)

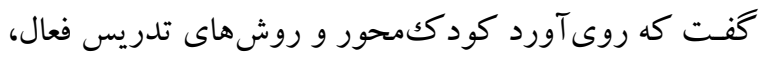
موثرتر از روى آورد معلممحور بوده اســـت و اين نتسايج بـا يززوهشهاى ييشـين كه در زمينه روى آوردهاى كود ككمحور

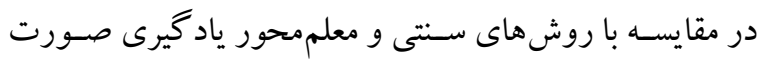
كرفته بودند در يكك جهت قرار دارد.

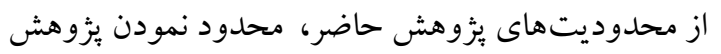
به مراكز بيشدبسـتانى يكك شـهر بود، بنابراين در تعميم نتايج

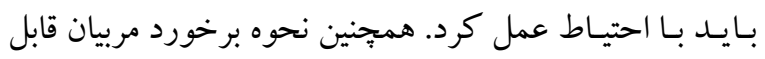

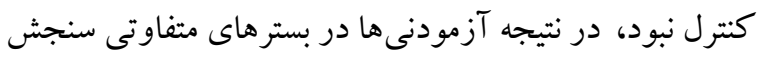

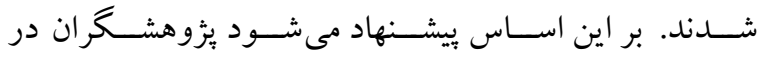
يثزوهشهاى آتى روابط بين فردى كودك با مربى و همسالان و 


\section{References}

1. Berk LE. Development through the lifespan. Sayed Mohammadi Y. (Persian translator). Seixth edition. Tehran: Arasbaran: 2017, pp: 268-278. [Persian].

2. MacBlain S. Learning theories for early years' practice. London: SAGE; 2018, pp: 52-57. [Link]

3. Malina RM, Bouchard C, Bar-Or O. Growth, maturation, and physical activity. Bahram A, Khalaji H. (Persian translator). Tehran: Omide Danesh; 2002, p: 275 [Persian].

4. Obrusnikova I, Cavalier A. An evaluation of videomodeling on fundamental motor skill performance of preschool children. Early Child Educ J. 2018; 46(3): 287-299. [Link]

5. Salehi H, Zarezade M. Prevalence distribution of fundamental movement skills in children of Tehran elementary schools. Journal of Motor Learning and Movement. 2016; 8(2): 281-299. [Persian]. [Link]

6. Shams A, Vameghi R. Relationship between age, gender and body mass index with performance of fundamental motor skills among children aged 7-10 years. Journal of Health Education and Health Pronation. 2018; 6(1): 39-52. [Persian]. [Link]

7. Lubans DR, Morgan PJ, Cliff DP, Barnett LM, Okely AD. Fundamental movement skills in children and adolescents. Sports Med. 2010; 40(12): 1019-1035. [Link]

8. Emarati FS, Namazizadeh M, Mokhtari P, Mohammadian F. Effects of selected elementary school games on the perceptual-motor ability and social growth of 8-to-9 year-old female students. Journal of Research in Rehabilitation Sciences. 2012; 7(5): 661-673. [Persian]. [Link]

9. Hoeboer J, Krijger-Hombergen M, Savelsbergh G, De Vries S. Reliability and concurrent validity of a motor skill competence test among 4- to 12-year old children. J Sports Sci. 2018; 36(14): 1607-1613. [Link]

10. Eyre ELJ, Walker LJ, Duncan MJ. Fundamental movement skills of children living in england: the role of ethnicity and native English language. Percept Mot Skills. 2018; 125(1): 5-20. [Link]

11. Haga M, Tortella P, Asonitou K, Charitou S, Koutsouki D, Fumagalli G, et al. Cross-cultural aspects: exploring motor competence among 7- to 8-year-old children from Greece, Italy, and Norway. SAGE Open. 2018; 8(2): 2158244018768381. [Link]

12. Nobre GC, Valentini NC, Nobre FSS. Fundamental motor skills, nutritional status, perceived competence, and school performance of Brazilian children in social vulnerability: Gender comparison. Child Abuse Negl. 2018; 80: 335-345. [Link]

13. Fotrousi F, Sheikh M, Hemayattalab R, Homanian D. Impact of badminton training course on compensating fundamental activities in children with motor lag. Journal of Research in Rehabilitation Sciences. 2018; 13(3): 138-144. [Persian]. [Link]

14. Fahimi M, Aslankhani M, Shojaee M, Beni M, Gholhaki M. The effect of four motor programs on motor proficiency in 7-9 years old boys. Middle-East Journal of Scientific Research. 2013; 13(11): 15261532. [Link]

15. Hamilton M, Liu T. The effects of an intervention on the gross and fine motor skills of Hispanic Pre-k children from low SES backgrounds. Early Child Educ J. 2018; 46(2): 223-230. [Link]

16. Yazdkhasti A. The role of preschool centers in the overall development of children. Journal of pyvand. 1998; 233: 48-58. [Persian].[link]

17. Kordi H, Sohrabi M, Saberi Kakhki A, Attarzadeh Hossini SR, Gholami A. The effect of feedback frequency on motor learning in children with developmental coordination disorder. Middle Eastern Journal of Disability Studies. 2017; 7. [Persian]. [Link]

18. Mofidi F. Management of pre-school centers. Eleventh edition. Tehran: Allameh Tabatabaei University Publication: 2014, p: 15 [Persian].

19. Şahin-Sak İT, Sak R, Tezel-Şahin F. Preschool teachers' views about classroom management models. Early Years. 2018; 38(1): 35-52. [Link]

20. Mofidi F. Preschool and Primary Education (Educational Science). Tehran: Payam Noor University Publication; 2014, p: 28 [Persian]. 
21. Cadima J, Barros S, Ferreira T, Serra-Lemos M, Leal T, Verschueren K. Bidirectional associations between vocabulary and self-regulation in preschool and their interplay with teacher-child closeness and autonomy support. Early Child Res Q. 2019; 46: 75-86. [Link]

22. Fox TA. Building a foundation in early childhood education: an analysis of the common core state standards and its influence on kindergarten [PHD thesis]. [New Haven, USA]: Southern Connecticut State University; 2018. [Link]

23. Wohlwend KE. Playing to our strengths: Finding innovation in children's imaginative expertise. Language Arts. 2018; 95(3): 162-170. [Link]

24. Ilgaz H, Hassinger-Das B, Hirsh-Pasek K, Golinkoff RM. Making the case for playful learning. In: Fleer M, van Oers B, editors. International handbook of early childhood education. Dordrecht: Springer Netherlands; 2018, pp: 1245-1263. [Link]

25. Liu C, Tobin J. Group exercise in Chinese preschools in an era of child-centered pedagogy. Comp Educ Rev. 2018; 62(1): 5-30. [Link]

26. Li X, Liu S, DeBey M, McFadden K, Pan Y-J. Investigating Chinese preschool teachers' beliefs in mathematics teaching from a cross-cultural perspective. Early Years. 2018; 38(1): 86-101. [Link]

27. Gullickson H, Cameron R, Marose L, Tiefenthaler I, Nice TV. Critique of the creative curriculum for preschool. University of Montana Journal of Early Childhood Scholarship and Innovative Practice. 2018; 2(1). [Link]

28. Arsham S, Sarabandi M, Sanaei F. The effect of social-comparative feedback and autonomy support on self-efficacy and children motor learning. Journal of Research in Behavioural Sciences. 2018; 15(4): 443-451. [Persian]. [Link]

29. Gol Mohammadnejhad G, Yekanizad A. Comparison of psycho-motor skills and social adjustment in students with and without pre-school experience. Quarterly Journal of Child Mental Health. 2017; 4(1): 78-87. [Persian]. [Link]

30. Hussain A, Juarez F, Li S, Estrada V, Johnstone J, Sosa E, et al. An eight-week physical activity intervention is associated with gross motor skills in preschool children. International Journal of Exercise Science: Conference Proceedings. 2018; 2(10). [Link]

31. Vazini Taher A, Hayati A, Pakzamir F. Relationship of level of physical activities and fundamental movement skills among elementary schools' children. Motor Behavior. 2014; 5(14): 163-178. [Persian]. [Link]

32. Brian A, Taunton S. Effectiveness of motor skill intervention varies based on implementation strategy. Phys Educ Sport Pedagogy. 2018; 23(2): 222-233. [Link]

33. Robinson LE, Webster EK, Logan SW, Lucas WA, Barber LT. Teaching practices that promote motor skills in early childhood settings. Early Child Educ J. 2012; 40(2): 79-86. [Link]

34. Hastie PA, Johnson JL, Rudisill ME. An analysis of the attraction and holding power of motor skill stations used in a mastery motivational physical education climate for preschool children. Phys Educ Sport Pedagogy. 2018; 23(1): 37-53. [Link]

35. Akbari B, Rahmati F. The efficacy of cognitive behavioral play therapy on the reduction of aggression in preschool children with attention-deficit/hyperactivity disorder. Quarterly Journal of Child Mental Health. 2015; 2(2): 93-100. [Persian]. [Link]

36. Torabi F, Aghayari A, Dashtabadi S. The effect of basic swimming skills training on gross motor skills in autistic children (7-11 years old). Journal of Motor Learning and Movement. 2015; 7(2): 171-185. [Persian]. [Link]

37. Engel AC, Broderick CR, van Doorn N, Hardy LL, Parmenter BJ. Exploring the relationship between fundamental motor skill interventions and physical activity levels in children: a systematic review and meta-analysis. Sports Med. 2018; 48(8): 1845-1857. [Link]

38. O'Connor S, Whyte EndaF, Gibbons B, Feeney O, Luc S, Ní Chéilleachair N. Fundamental movement skill proficiency in juvenile Gaelic games. Sport Sci Health. 2018; 14(1): 161-172. [Link]

39. Clark CCT, Moran J, Drury B, Venetsanou F, Fernandes JFT. Actual vs. Perceived motor competence in children (8-10 years): an issue of non-veridicality. J Funct Morphol Kinesiol. 2018; 3(2): 20. [Link] 
40. Angell RM, Butterfield SA, Tu S, Loovis EM, Mason CA, Nightingale CJ. Children's throwing and striking: a longitudinal study. J Mot Learn Dev. 2018; 6(2): 315-332. [Link]

41. Fu Y, Burns RD. Demographic characteristics related to motor skills in children aged 5-7 years old. International Journal of Kinesiology and Sports Science. 2018; 6(2): 15-21. [Link]

42. Taunton SA, Mulvey KL, Brian AS. Who SKIPS? Using temperament to explain differential outcomes of a motor competence intervention for preschoolers. Res Q Exerc Sport. 2018; 89(2): 200-209. [Link]

43. Soltanian MA, Farokhi A, Ghorbani R, Jaberi AA, Zarezade M. Evaluation of the reliability and construct validity of test of gross motor development-2 (Ulrich 2) in children of Semnan province. Koomesh. 2013; 14(2): 200-206. [Persian]. [Link]

44. Ulrich DA, Sanford CB. Test of gross motor development: examiner's manual. Austin, Tex. (8700 Shoal Creek Blvd., Austin 78757): Pro-Ed; 2000. [Link]

45. Robinson LE. The relationship between perceived physical competence and fundamental motor skills in preschool children. Child Care Health Dev. 2011; 37(4): 589-596. [Link]

46. Şahin-Sak IT, Tantekin-Erden F, Pollard-Durodola S. Turkish preschool teachers' beliefs and practices related to two dimensions of developmentally appropriate classroom management. Educ 3 13. 2018; 46(1): 102-116. [Link]

47. Clark JE, Clements RL, Guddemi M, Morgan DW, Pica R, Pivarnik JM, et al. Active start: a statement of physical activity guidelines for children birth to five years. AAHPERD Publications, P; 2002. [Link] 